\title{
Testing Efficacy of Small Group Discussion in Educating Teen-Age Girls
}

\author{
Kumari Madhu* and Punam Kumari \\ Department of Home Science Extension and Communication Management College of \\ Community Science DRPCAU, Pusa Samastipur, Bihar, India \\ *Corresponding author
}

\section{A B S T R A C T}

\section{Keywords}

Active Learning , Small Group

Discussion, Teen

Age Girls, Validity, Reliability

\section{Article Info}

Accepted:

12 February 2020

Available Online:

10 March 2020
Evidences have shown that Active learning methods are directly associated with students' engagement in the process of learning and there by improvement in their learning outcome. To test this empirically, the researcher chose to work upon testing the efficacy of small group discussion brining change in pupil's learning outcome as compared to lecture alone. For the purpose, test material on 'importance of protein for human body' was developed and knowledge test prepared accordingly. The research design selected for the study was pre-test post-test control group design. Control and experimental groups each of 25 intermediate level students were farmed. Knowledge-test was given to both the groups before delivering the lecture. After the pre-test was over; the groups were given the preknowledge test. After the pre-test, lecture was given to both the groups. Then the groups were separated and experimental group was assigned to hold small group discussion by making a group of five each. Both the groups were their fed the knowledge-test again and their mean difference score between pre and post knowledge test was calculated separately. The mean difference score for experimental group was thus 4.00 , while it was 1.24 in case of control group. The difference in pre-test, post -test score was found to be significant with a calculated ' $t$ ' value of 2.18 and 5.00 for control and experimental group respectively The t-value being significant at one percent level for experimental group. It was thus concluded that the lecture along with small group discussion was more effective for educating teen-age girls than lecture alone.

\section{Introduction}

Active learning is a method of instruction that focuses the responsibility of learning on the learners. It was popularized in the 1990s by its appearance on the Association for the Study of Higher Education (ASHE) report (Bonwell \& Eison 1991). They referred that to learn, students must do more than just listening: They must read, write, discuss, or be engaged in solving problems. "Active learning" as a pedagogical approach is by no means a novel concept.

Colleges and universities throughout the country explored a more involved approach to instruction after having criticism of more passive teaching methods levelled at the institutions during the 1980s. (Meyers and Jones, 1993). It is safe to say that active 
learning is characterized by a marked departure from the traditional lecture format, where students passively receive information, towards an approach which induces specific student engagement and activity in learning (Prince, 2004). An examination of the literature reveals that active learning is usually defined as a set of specific instructional methods that promote greater student involvement and responsibility for learning than traditional instructional approaches (Bonwell and Eison, 1991).

The key ingredient to active learning is some structured activity that significantly increases the level of student's engagement in the learning process. Ideally, a concomitant benefit of active learning is a shift in the role of the typical instructor as a "knowledge provider" to that of a guide, gently directing the student's attention to key landmarks along his intellectual journey. In other words, active learning is the antithesis of the classroom lecture, where educators talk and students listen. (Meyers and Jones, 1993).

It relates to the three learning domains referred to as knowledge, skills and attitudes (KSA), and that this taxonomy of learning behaviours can be thought of as "the goals of the learning process" (Bloom, 1956).

Students and their learning needs are the center of active learning. There are several teaching strategies that can be employed to actively engage students in the learning process, including group discussions, problem solving, case studies, role plays, journal writing, and structured learning groups.

The benefit of using such activities is many. These include improved critical thinking skills, increased retention and transfer of new information, increased motivation, and improved interpersonal skills in learners. The present study was thus planned and conducted with the following specific objective:

To select and standardise the test material for Active Learning i.e., Small Group Discussion.

To test the efficacy of Small Group Discussion in educating teen-age girls.

\section{Methodology}

The research methodology for the present study has been discussed under two heads.

\section{Selection and standardization of test - material}

Testing efficacy of active learning method (small group discussion) in educating teenage girls through the test- material prepared

Fifty knowledge test items on 'importance of protein for human body' was initially prepared with the help of concerned subjectmatter specialists i.e.,faculty members. These items were then given to those faculty members after an interval of fifteen days those who were not included at the initial stage. It was done to determine the appropriateness of items for inclusion in the knowledge test.

The appropriateness scale consisted of three degrees of 'very appropriate,' 'appropriate' and 'not at all appropriate' which was scored as 2, 1 and 0 respectively. Finally, thirty knowledge test items based on mean score distribution in descending order was selected.

The reliability of the test items was determined using test-retest method for those thirty items.

In this way, thirty knowledge-test items were finally selected for knowledge test to be developed for testing the efficacy of lecture 
and lecture combined with small group discussion in educating teen-age girls.

The Research design used for the study was pre-test, post -test control group design. The study was conducted in Pusa Block of Samastipur District of Bihar. The knowledge test prepared was fed to the fifty students divided into control and experimental groups of twenty-five each.

Assignment of treatment according to research design was as follows:

\begin{tabular}{|l|l|l|l|l|}
\hline Group & Treatment & Pre-test & Treatment & Post- test \\
\hline Control group & Nil & 01 & Lecture & 02 \\
\hline $\begin{array}{l}\text { Experimental } \\
\text { group }\end{array}$ & Nil & 03 & $\begin{array}{l}\text { Lecture followed by Small } \\
\text { group discussion }\end{array}$ & 04 \\
\hline
\end{tabular}

Both the groups were then taken apart and experimental group was broken into five small groups. The groups thus broken were allowed to hold group discussion for about 10-15 minutes on the delivered topic. They were fed the knowledge -test again after discussion. The data for both the groups were collected before and after the treatment.

The dichotomous knowledge items included in the knowledge test were quantified in terms of one score for correct answer and zero for incorrect answer. Thus on thirty items knowledge test the score ranged from zero to thirty. The mean gain in knowledge was calculated to see the difference between groups before and after the treatment.

\section{Results and Discussion}

Using the variance technique the analysed data showed that the mean difference score was 15.32 (Table 1) before treatment in control group, however, after the treatment i.e., after delivering the lecture, the mean knowledge score rose to 16.56 with a remarkable difference of 1.24 and calculated " $t$ ' value of 2.18 which was significant at five percent level of probability.

The observed data for experimental group showed a mean score value of 19.48 having the mean difference of 4.00 score between pre-test, post-test. The ' $t$ ' value thus calculated was 5.00 being significant at one percent level of probability.

Table.1 Mean difference score of post-test and pre-test for control group and experimental group

\begin{tabular}{|l|r|c|c|c|}
\hline \multicolumn{1}{|c|}{ Group } & \multicolumn{3}{|c|}{$\begin{array}{c}\text { Mean knowledge score } \\
\text { Treatment }\end{array}$} & $\begin{array}{c}\text { Calculated } \\
\text { 't' }\end{array}$ \\
\cline { 1 - 5 } & $\begin{array}{l}\text { Before } \\
\text { exposure }\end{array}$ & $\begin{array}{l}\text { After } \\
\text { exposure }\end{array}$ & Difference & \\
\hline Control group (Lecture) $\mathbf{N = 2 5}$ & 15.32 & 16.56 & 1.24 & $2.18^{*}$ \\
\hline $\begin{array}{l}\text { Experimental group (Lecture+ } \\
\text { Small Group Discussion) }\end{array}$ & 15.48 & 19.48 & 4.00 & $5.00^{* *}$ \\
\hline
\end{tabular}

* Significant at five percent level of Probability.

** Significant at one percent level of Probability. 
The study concluded that the lecture along with small group discussion was more effective for educating teen - age girls than lecture alone. It is thus advocated that use of active learning methodologies in class-room instruction be promoted in order to increase the effectiveness and retention of material learnt which is in consonance with the goal of teaching learning process.

\section{References}

Bloom, B.(1956). Taxonomy of Educational Objectives: The Classification of Educational Goals. New York: McKay.
Bonwell, C. \&Eison, J. (1991). Active learning: Creating excitement in the classroom. Retrieved from ERIC Clearinghouse on Higher Education Washington DC.| FGK28050 _George Washington University, Washington DC.

Meyers, C.\& Jones, T. B. (1993). Promoting active learning: Strategies for the college classroom. San Francisco: Jossey-Bass.

Prince, M. (2004). Does active learning work? A review of the research. Journal of engineering education,93(3), 223-231.

\section{How to cite this article:}

Kumari Madhu and Punam Kumari. 2020. Testing Efficacy of Small Group Discussion in Educating Teen-Age Girls. Int.J.Curr.Microbiol.App.Sci. 9(03): 1485-1488.

doi: https://doi.org/10.20546/ijcmas.2020.903.173 